\title{
PENILAIAN KINERJA KEUANGAN PERUSAHAAN DENGAN ANALISIS DU PONT SYSTEM STUDI KASUS PADA EMPAT PERUSAHAAN TELEKOMUNIKASI YANG TERDAFTAR DI BURSA EFEK INDONESIA PERIODE TAHUN 2014 - 2018
}

\author{
A.Yuliatma Hidayat \\ ayuliatmahidayat@gmail.com \\ Indianik Aminah \\ indianikmashuri@gmail.com \\ Novitasari \\ novitasari26@gmail.com \\ Program Studi Akuntansi Keuangan Terapan Politeknik Negeri Jakarta
}

\begin{abstract}
The purpose of this research is to find out how the financial performance of PT Telekomunikasi Indonesia Tbk, PT XL Axiata Tbk, PT Indosat Tbk and PT Smartfren Telecom Tbk by using the Du Pont System Method. Data analysis method used in this research is Du Pont System Method. The variables used in this study are Total Asset Turnover (TATO), Net Profit Margin (NPM), and Return on Investment (ROI). The data used are secondary data in the form of company financial statements. The results showed that PT Telekomunikasi Indonesia Tbk has a very good financial performance where all variables are above the industry average. PT XL Axiata Tbk has a fairly good financial performance because only the Net Profit Margin variable is above the industry average. PT Indosat has a relatively good financial performance where only the Total Asset Turnover variable is above the industry average. PT Smartfren Telecom Tbk has poor financial performance because all variables are below the industry average.
\end{abstract}

Keywords: Du Pont System, Return On Investment, Net Profit Margin, Total Asset Turnover

\section{ABSTRAK}

Tujuan Penelitian ini adalah untuk mengetahui bagaimana kinerja keuangan perusahaan PT Telekomunikasi Indonesia Tbk, PT XL Axiata Tbk, PT Indosat Tbk dan PT Smartfren Telecom Tbk dengan menggunakan Metode Du Pont System. Metode analisis data yang digunakan dalam penelitian ini adalah Metode Du Pont System. Variabel yang digunakan dalam penelitian ini adalah Total Asset Turnover (TATO), Net Profit Margin (NPM), dan Return On Investment (ROI). Data yang digunakan merupakan data sekunder berupa laporan keuangan perusahaan. Hasil penelitian menunjukkan bahwa PT Telekomunikasi Indonesia Tbk memiliki kinerja keuangan yang sangat baik dimana semua variabel berada diatas rata-rata industri. PT XL Axiata Tbk memiliki kinerja keuangan yang cukup baik karena hanya variabel Net Profit Margin yang berada diatas rata-rata industri. PT Indosat tbk memiliki kinerja keuangan yang cukup baik dimana hanya variabel Total Asset Turnover yang berada diatas rata-rata industri. PT Smartfren Telecom Tbk memiliki kinerja keuangan yang tidak baik karena semua variabel berada dibawah rata-rata industri.

Kata kunci: Du Pont System, Return on Investment, Net Profit Margin, Total Asset Turnover.

\section{PENDAHULUAN}

\section{Latar Belakang Masalah}

Perkembangan perekonomian di Indonesia sekarang telah memasuki era digital ekonomi dan industri 4.0 yang dipengaruhi oleh perubahan sosial dan tingkat persaingan yang sangat tinggi. Perkembangan ekonomi digital di Indonesia didorong oleh beberapa faktor seperti dijelaskan oleh Direktur Jenderal Sumber Daya dan Perangkat Pos dan Informatika (SDPPI) Kementerian Komunikasi dan Informatika,
Ismail, yaitu salah satu faktor yang memiliki peran yang signifikan dalam mendorong perkembangan ekonomi digital di Indonesia adalah perkembangan industri telekomunikasi.

Menteri Komunikasi dan Informatika,

Tifatul Sembiring menjelaskan Indonesia merupakan pasar potensial bagi perkembangan industri telekomunikasi. Apalagi jumlah penduduk yang besar bakal menjadi konsumen potensial bagi produsen telekomunikasi (indotelco.com, 2018). Hal itu disebabkan 
karena telekomunikasi dan masyarakat merupakan dua hal yang sudah sulit untuk dipisahkan dimana tingkat kemajuan penggunaan internet yang semakin pesat. Pada tahun 2018 tingkat kemajuan penggunaan internet memberikan tekanan yang sangat berat untuk industri telekomunikasi di Indonesia karena mengalami pertumbuhan negatif (kontraksi). Pertumbuhan negatif yang terjadi dapat dilihat sepanjang semester 1-2018, kinerja operator sungguh-sungguh dalam tekanan.

Pertumbuhan negatif ini mengakibatkan perusahaan telekomunikasi mengalami penurunan laba bahkan rugi yang sangat tinggi. Dalam hal ini perusahaan harus melakukan penilaian kinerja untuk melihat apa yang menyebabkan pertumbuhan negatif ini terjadi. Salah satu bentuk informasi yang dapat digunakan untuk mengetahui kondisi kinerja keuangan dan perkembangan perusahaan adalah adanya laporan keuangan. Analisis laporan keuangan ini menggunakan metode analisis Du Pont System dengan tiga variabel yaitu Total Asset Turnover (TATO), Net Profit Margin (NPM), dan Return On Investment (ROI).

\section{Permasalahan}

Berdasarkan permasalahan pada latar belakang, maka rumusan masalah yang akan diteliti pada penelitian ini adalah:

1. Bagaimanakah kinerja keuangan empat perusahaan telekomunikasi yang terdaftar di BEI pada periode tahun 2014 sampai 2018 dengan menggunakan metode analisis $D u$ pont System?

2. Bagaimanakah implikasi penilaian kinerja keuangan perusahaan dengan metode analisis Du Pont System untuk keempat perusahaan telekomunikasi yang terdaftar di BEI pada periode tahun 2014 sampai 2018 ?

\section{Tujuan}

Merujuk pada permasalahan dan pertanyaan penelitian, penelitian ini bertujuan untuk:

1. Untuk mengetahui kinerja keuangan empat perusahaan telekomunikasi yang terdaftar di BEI pada periode tahun 2014 sampai 2018 dengan menggunakan metode analisis Du pont System.

2. Untuk mengetahui implikasi penilaian kinerja keuangan perusahaan dengan metode analisis Du Pont System untuk keempat perusahaan telekomunikasi yang terdaftar di BEI pada periode tahun 2014 sampai 2018.

\section{TINJAUAN PUSTAKA}

\section{Kinerja Keuangan Perusahaan}

Kinerja keuangan merupakan gambaran kondisi perusahaan pada suatu periode tertentu baik menyangkut aspek penghimpunan dana maupun penyaluran dana yang diukur dengan alat-alat analisis keuangan sehingga dapat diketahui mengenai baik buruknya keadaan keuangan pada perusahaan tersebut.

\section{Laporan Keuangan Perusahaan}

Laporan keuangan perusahaan merupakan suatu informasi yang menggambarkan kondisi keuangan suatu perusahaan dan untuk membantu membuat keputusan investor yang ingin membeli atau menjual saham bisa terbantu dengan memahami dan menganalisis laporan keuangan hingga selanjutnya bisa menilai perusahaan mana yang memiliki prospek yang menguntungkan di masa depan.

\section{Analisis Laporan Keuangan}

Analisis laporan keuangan merupakan proses yang penuh pertimbangan dalam rangka membantu mengevaluasi posisi keuangan dan hasil operasi perusahaan pada masa sekarang dan masa lalu, dengan tujuan untuk menentukan estimasi dan prediksi yang paling mungkin mengenai kondisi dan kinerja perusahaan pada masa mendatang.

\section{Rata-rata Industri}

Rata-rata industri menggunakan salah satu bentuk statistika dengan nilai tunggal sebagai perbandingan. Menghitung nilai tunggal bisa menggunakan alternatif rumus Aritmatika. Standar rasio yang baik adalah yang memberikan gambaran rata-rata. Gambaran rata-rata yang paling tepat adalah rasio industri atau lebih dikenal rata-rata industri (gabungan perusahaan sejenis). Rumus perhitungan rata-rata industri per variabel sebagai berikut:

\section{Analisis Du Pont System}

Analisis Du Pont mengembangkan analisis yang memisahkan profitabilitas dengan pemanfaatan aset (asset utilization). Analisis ini menggabungkan tiga macam rasio sekaligus yaitu ROI, profit margin, dan perputaran aktiva 
(total asset turnover). Pada dasarnya digunakan untuk dapat mengevaluasi efektifitas perusahaan dengan melihat bagaimana pengembalian atas investasi perusahaan tersebut.

\section{METODE PENELITIAN Jenis Penelitian}

Penelitian yang dilakukan oleh penulis menggunakan penelitian deskriptif dengan pendekatan kuantitatif, dimana hasil penelitian yang penulis sajikan berupa perbandingan antara beberapa variabel. Penelitian deskriptif bertujuan untuk menggambarkan atau mendefinisikan apa saja yang terlibat dalam suatu kegiatan, apa yang dilakukan, dan bagaimana cara melakukannya. Penelitian deskriptif tidak dimaksudkan untuk menguji hipotesis tetapi hanya menggambarkan apa adanya tentang keadaan suatu variabel, gejala dan keadaannya.

\section{Objek Penelitian}

Laporan keuangan empat perusahaan telekomunikasi yang terdaftar di Bursa Efek Indonesia yaitu PT Telekomunikasi Indonesia (Persero) Tbk, PT XL Axiata Tbk, PT Indosat Tbk, dan PT Smartfren Telecom Tbk periode 2014-2018.

\section{Jenis Data dan Sumber Data}

Data penelitian ini menggunakan data sekunder yang diperoleh dari Bursa Efek Indonesia (IDX) yang diambil melalui website IDX yaitu www.idx.co.id.

\section{Metode Pengumpulan Data}

Metode pengumpulan data menggunakan teknik dokumentasi yang diambil dari laporan keuangan PT Telekomunikasi Indonesia (Persero) Tbk, PT XL Axiata Tbk, PT Indosat Tbk, dan PT Smartfren Telecom Tbk periode tahun 20142018.

\section{Analisis Data}

Teknik analisis data dalam penelitian ini adalah untuk mengetahui kinerja keuangan perusahaan dengan menggunakan analisis metode Du Pont System berdasarkan laporan keuangan perusahaan yang terdiri dari neraca dan laporan laba rugi tahun 2014 sampai dengan tahun 2018. Adapun langkah-langkah dalam penelitian ini adalah sebagai berikut:

\section{Pengumpulan Data}

Pengumpulan data yang merupakan laporan keuangan perusahaan dilakukan dengan mengunduh langsung dari website resmi Bursa Efek Indonesia. Jenis laporan keuangan yang digunakan dalam penelitian ini adalah laporan posisi keuangan dan laporan laba rugi PT Telekomunikasi Indonesia (Persero) Tbk, PT XL Axiata Tbk, PT Indosat Tbk, dan PT Smartfren Telecom Tbk persemester Tahun 2014-2018.

2. Menghitung Rata-rata Industri

Perhitungan rata-rata industri dilakukan pada masing-masing variabel yang dilakukan dengan menggunakan teknik aritmatika sebagai berikut:

a. Rata- Rata Industri ROI

$$
\text { Rata }- \text { rata Industri } R O I=\frac{\text { Total ROI Perusahaan }}{\text { Total Perusahaan }}
$$

b. Rata- Rata Industri NPM

Rata - rata Industri NPM $=\frac{\text { Total NPM Perusahaan }}{\text { Total Perusahaan }}$

c. Rata- Rata Industri TATO

Rata - rata Industri TATO $=\frac{\text { Total TATO Perusahaan }}{\text { Total Perusahaan }}$

\section{Menghitung Perputaran Total Aktiva/}

\section{Total Asset Turnover}

Mengukur perputaran dari semua aset yang dimiliki perusahaan. Berikut ini rumus yang digunakan:

$$
\text { Total Assets Turnover }=\frac{\text { Penjualan bersih }}{\text { Total Asset }}
$$

Keterangan:

Total Assets Turnover $=$ Perputaran total aktiva dimana seluruh total aktivanya digunakan untuk mengukur perputaran semua aset yang dimiliki oleh perusahaan.

\section{Menghitung Rasio Laba Bersih/ Net Profit Margin}

Net Profit Margin adalah rasio yang mengukur sejauh mana kemampuan suatu perusahaan menghasilkan laba bersih pada tingkat penjualan tertentu, Rasio ini juga diinterpretasikan juga sebagai kemampuan perusahaan menekan biaya-biaya (ukuran efisiensi) di perusahaan pada periode tertentu. Berikut rumus untuk menghitung Net Profit Margin : 
Net Profit Margin $=\frac{\text { Laba Bersih setelah pajak }}{\text { Total Penjualan Bersih }} \times 100 \%$

\section{Menghitung Return On Investment (ROI)}

Metode analisis Du Pont System ini menggunakan pendekatan tertentu dari analisis rasio untuk mengevaluasi efektivitas perusahaan. ROI dapat mengukur tingkat keuntungan yang dihasilkan dari investasi total perusahaan. Dalam menghitung rasio ini maka rumus yang digunakan adalah sebagai berikut:

Return on investment $=\frac{\text { Laba bersih setelah pajak }}{\text { Total Asset }} \times 100 \%$

\section{Menilai Kinerja Keuangan Perusahaan}

Menilai Kinerja keuangan perusahaan dan membandingkan variabel-variabel yang telah diteliti menggunakan metode analisis $D u$ Pont System berdasarkan kriteria yang ada, adapun kriteria kinerja keuangan perusahaan yang ideal berdasarkan masing-masing variabel adalah sebagai berikut:

a. Kriteria kinerja keuangan perusahaan yang baik yaitu Du Pont System atau Return On Investment berada di atas rata-rata industri yang menunjukkan bahwa perputaran aktiva dan Net Profit Margin sangat tinggi. Hal ini menunjukkan bahwa kinerja keuangan perusahaan dalam menghasilkan laba semakin baik.

b. Kriteria kinerja keuangan perusahaan yang kurang baik yaitu Du Pont System atau Return On Investment dibawah rata-rata industri yang menunjukkan bahwa perputaran aktiva dan Net Profit Margin sangat rendah. Hal ini menunjukkan bahwa kinerja keuangan perusahaan dalam menghasilkan laba kurang baik.

\section{METODE PENELITIAN}

Penelitian ini menggunakan pendekatan kualitatif dengan analisis isi. Adapun langkah-langkah yang dilakukan dalam penelitian ini dengan menggunakan pendekatan studi literatur yaitu dengan melakukan pencarian terhadap berbagai sumber tertulis ataupun online baik berupa buku-buku, arsip, majalah, artikel, atau dokumen-dokumen yang relevan untuk diidentifikasikan, diklasifikasikan, dan disimpulkan. Data dan informasi tersebut selanjutnya dielaborasi sebagai dasar analisis penelitian. Dari tahapan tersebut dapat diperoleh kesimpulan sementara, untuk selanjutnya dielaborasi dengan berbagai literatur terkait. Selain itu, beberapa data diperoleh dari situs www.idx.co.id, www.djppr.kemenkeu.go.id, www.dsnmui.or.id.

\section{HASIL DAN PEMBAHASAN}

Hasil Perhitungan Rata-rata Industri

Berikut ini hasil perhitungaan rata-rata industri dari empat perusahaan telekomunikasi di Indonesia yang terdaftar di BEI periode tahun 2014-2018 yang merupakan pembanding dalam menilai kinerja keuangan perusahaan:

\begin{tabular}{|c|c|r|r|r|}
\hline \multicolumn{2}{|c|}{ KETERANGAN/TAHUN } & \multicolumn{1}{c|}{ TATO } & \multicolumn{1}{c|}{ NPM } & \multicolumn{1}{c|}{ ROI } \\
\hline $\mathbf{2 0 1 4}$ & I & 0,21 KALI & $-8,7 \%$ & $0,3 \%$ \\
\hline & II & 0,41 KALI & $-8,6 \%$ & $0,6 \%$ \\
\hline $\mathbf{2 0 1 5}$ & I & 0,20 KALI & $-11,0 \%$ & $0,1 \%$ \\
\hline & II & 0,41 KALI & $-8,4 \%$ & $1,1 \%$ \\
\hline $\mathbf{2 0 1 6}$ & I & 0,22 KALI & $-2,6 \%$ & $1,7 \%$ \\
\hline & II & 0,44 KALI & $-5,8 \%$ & $2,7 \%$ \\
\hline $\mathbf{2 0 1 7}$ & I & 0,24 KALI & $-5,0 \%$ & $1,7 \%$ \\
\hline & II & 0,46 KALI & $-8,3 \%$ & $1,8 \%$ \\
\hline $\mathbf{2 0 1 8}$ & I & 0,21 KALI & $-11,4 \%$ & $-0,3 \%$ \\
\hline & II & 0,42 KALI & $-16,9 \%$ & $-2,7 \%$ \\
\hline
\end{tabular}

\section{PT Telekomunikasi Indonesia Tbk}

Berikut ini hasil penilaian kinerja keuangan perusahaan PT Telekomunikasi Indonesia Tbk periode tahun 2014-2018:

\begin{tabular}{|c|c|c|c|c|}
\hline \multicolumn{2}{|c|}{ KETERANGAN/TAHUN } & TATO & NPM & ROI \\
\hline $\mathbf{2 0 1 4}$ & I & 0,33 KALI & $24,0 \%$ & $8,0 \%$ \\
\hline & II & 0,63 KALI & $23,7 \%$ & $15,0 \%$ \\
\hline $\mathbf{2 0 1 5}$ & I & 0,32 KALI & $22,5 \%$ & $7,1 \%$ \\
\hline & II & 0,62 KALI & $22,8 \%$ & $14,0 \%$ \\
\hline $\mathbf{2 0 1 6}$ & I & 0,33 KALI & $26,0 \%$ & $8,6 \%$ \\
\hline & II & 0,65 KALI & $25,1 \%$ & $16,2 \%$ \\
\hline $\mathbf{2 0 1 7}$ & I & 0,36 KALI & $27,3 \%$ & $9,8 \%$ \\
\hline & II & 0,65 KALI & $25,5 \%$ & $16,5 \%$ \\
\hline $\mathbf{2 0 1 8}$ & I & 0,32 KALI & $19,9 \%$ & $6,3 \%$ \\
\hline & II & 0,63 KALI & $20,6 \%$ & $13,1 \%$ \\
\hline
\end{tabular}

Berdasarkan hasil penilaian kinerja diatas dapat dilihat kondisi perusahaan dari variabel Total asset Turnover dari perusahaan ini dari tahun 2014 sampai dengan tahun 2018 selalu berada diatas rata-rata industry. Hal tersebut menunjukkan bahwa Kinerja keuangan PT Telekomunikasi Indonesia dalam menghasilkan penjualan dari total aset yang dimiliki dikatakan sangat tinggi. Variabel Net Profit Margin Net Profit Margin dari perusahaan ini selama tahun 2014 sampai dengan 2018 selalu berada diatas rata-rata 
industri. Hal tersebut menunjukkan bahwa kinerja keuangan PT Telekomunikasi Indonesia dalam memperoleh laba bersih dari penjualan dikatakan sangat tinggi. Return On Investment perusahaan ini selama tahun 2014 sampai dengan 2018 selalu berada diatas rata-rata industri sektor telekomunikasi. Hal tersebut menunjukkan bahwa kinerja keuangan PT Telekomunikasi Indonesia dalam memperoleh pengembalian atas aset dari laba bersih penjualan sangat baik.

\section{PT XL Axiata Tbk}

Berikut ini hasil penilaian kinerja keuangan perusahaan PT XL Axiata Tbk periode tahun 2014-2018:

\begin{tabular}{|c|c|c|c|c|}
\hline \multicolumn{2}{|c|}{ KETERANGAN/TAHUN } & TATO & NPM & ROI \\
\hline $\mathbf{2 0 1 4}$ & I & 0,20 KALI & $-4,2 \%$ & $-0,8 \%$ \\
\hline & II & 0,37 KALI & $-3,8 \%$ & $-1,4 \%$ \\
\hline $\mathbf{2 0 1 5}$ & I & 0,18 KALI & $-7,7 \%$ & $-1,4 \%$ \\
\hline & II & 0,39 KALI & $-0,1 \%$ & $0,0 \%$ \\
\hline $\mathbf{2 0 1 6}$ & I & 0,18 KALI & $2,1 \%$ & $0,4 \%$ \\
\hline & II & 0,39 KALI & $1,8 \%$ & $0,7 \%$ \\
\hline $\mathbf{2 0 1 7}$ & I & 0,20 KALI & $1,3 \%$ & $0,3 \%$ \\
\hline & II & 0,41 KALI & $1,6 \%$ & $0,7 \%$ \\
\hline $\mathbf{2 0 1 8}$ & I & 0,20 KALI & $-0,7 \%$ & $-0,1 \%$ \\
\hline & II & 0,40 KALI & $-14,4 \%$ & $-5,7 \%$ \\
\hline
\end{tabular}

Berdasarkan hasil penilaian kinerja diatas dapat dilihat kondisi perusahaan dari variabel Total asset Turnover dari perusahaan ini selama tahun 2014 sampai dengan 2018 berada dibawah rata-rata industri akan tetapi tidak terlalu jauh dari rata-rata industri. Hal tersebut menunjukkan bahwa kinerja keuangan PT XL Axiata Tbk dalam menghasilkan penjualan dari total aset yang dimiliki dikatakan masih rendah dibandingkan dengan PT Telekomunikasi Indonesia. Tingkat Net Profit Margin dari perusahaan ini selama tahun 20142018 sangat rendah dimana awal tahun 2014 dan 2015 karena mengalami kerugian. Net Profit Margin dari PT XL Axiata ini juga berada diatas rata-rata industri walaupun dengan nilai negatif akan tetapi tetap bisa berada diatas rata-rata industri. Hal tersebut menunjukkan bahwa kinerja keuangan PT XL Axiata Tbk dalam memperoleh laba bersih dari penjualan dikatakan masih baik walaupun tidak setinggi PT Telekomunikasi Indonesia. Tingkat Return On Investment dari perusahaan ini selama tahun 2014 sampai dengan 2018 hampir semua berada dibawah rata-rata industri sektor telekomunikasi kecuali pada tahun 2018 semester 1 yang berada diatas ratarata industri. Hal tersebut menunjukkan kinerja keuangan PT XL Axiata Tbk dalam memperoleh pengembalian atas aset dari penjualan masih kurang baik yang dipengaruhi oleh kemampuan perusahaan dalam perputaran aset yang masih kurang baik dan dalam menghasilkan laba bersih dari penjualannya yang masih kurang baik.

\section{PT Indosat Tbk}

Berikut ini hasil penilaian kinerja keuangan perusahaan PT Indosat Tbk periode tahun 2014-2018:

\begin{tabular}{|c|c|c|c|c|}
\hline \multicolumn{2}{|c|}{ KETERANGAN/TAHUN } & TATO & NPM & ROI \\
\hline $\mathbf{2 0 1 4}$ & I & $0,22 \mathrm{KALI}$ & $-9,1 \%$ & $-2,0 \%$ \\
\hline & II & $0,46 \mathrm{KALI}$ & $-7,7 \%$ & $-3,6 \%$ \\
\hline $\mathbf{2 0 1 5}$ & I & $0,22 \mathrm{KALI}$ & $-5,3 \%$ & $-1,1 \%$ \\
\hline & II & $0,48 \mathrm{KALI}$ & $-4,3 \%$ & $-2,1 \%$ \\
\hline $\mathbf{2 0 1 6}$ & I & $0,28 \mathrm{KALI}$ & $3,6 \%$ & $1,0 \%$ \\
\hline & II & $0,57 \mathrm{KALI}$ & $4,4 \%$ & $2,5 \%$ \\
\hline $\mathbf{2 0 1 7}$ & I & $0,31 \mathrm{KALI}$ & $5,8 \%$ & $1,8 \%$ \\
\hline & II & $0,59 \mathrm{KALI}$ & $4,4 \%$ & $2,6 \%$ \\
\hline $\mathbf{2 0 1 8}$ & I & $0,22 \mathrm{KALI}$ & $-3,9 \%$ & $-0,9 \%$ \\
\hline & II & $0,44 \mathrm{KALI}$ & $-9,0 \%$ & $-3,9 \%$ \\
\hline
\end{tabular}

Berdasarkan hasil penilaian kinerja diatas dapat dilihat kondisi perusahaan dari variabel Total asset Turnover dari perusahaan ini selama tahun 2014 sampai dengan 2018 berada diatas rata-rata industri. Hal tersebut menunjukkan bahwa PT Indosat Tbk menghasilkan penjualan dari perputaran total aset yang dimiliki dikatakan tinggi walaupun memiliki penjualan dan total aset yang naik turun selama tahun 2014-2018. Tingkat Net Profit Margin dari PT Indosat Tbk ini juga berada jauh dibawah ratarata industri kecuali pada tahun 2018 semester 2 yang lebih tinggi dari rata-rata industri tapi dengan nilai yang masih negatif. Hal tersebut menunjukkan bahwa kinerja keuangan PT Indosat Tbk dalam memperoleh laba bersih dari penjualan dikatakan rendah walaupun pada tahun 2016 dan 2017 perusahaan masih bisa memperoleh laba tetapi pada tahun 2018 perusahaan kembali mengalami kerugian yang sepertinya dipengaruhi oleh keadaan industri telekomunikasi pada tahun 2018 dilihat dari sisi Net Profit Margin sedang dalam kondisi yang tidak stabil. Tingkat Return On Investment dari perusahaan ini selama tahun 2014 sampai dengan 2018 berada dibawah rata-rata industri sektor telekomunikasi. Hal tersebut menunjukkan bahwa kinerja keuangan PT Indosat Tbk dalam memperoleh pengembalian atas aset dari penjualan masih kurang baik yang dipengaruhi oleh kemampuan perusahaan dalam menghasilkan laba bersih dari penjualannya yang kurang baik.

\section{PT Smartfren Telecom Tbk}


Account: Vol 7 No 2 A.Yuliatma Hidayat, Indianik Aminah, Novitasari.

Berikut ini hasil penilaian kinerja keuangan perusahaan PT Smartfren Telecom Tbk periode tahun 2014-2018:

\begin{tabular}{|c|c|c|c|c|}
\hline \multicolumn{2}{|c|}{ KETERANGAN/TAHUN } & TATO & NPM & ROI \\
\hline $\mathbf{2 0 1 4}$ & I & 0,08 KALI & $-45,5 \%$ & $-3,8 \%$ \\
\hline & II & 0,17 KALI & $-46,7 \%$ & $-7,8 \%$ \\
\hline $\mathbf{2 0 1 5}$ & I & 0,08 KALI & $-53,7 \%$ & $-4,3 \%$ \\
\hline & II & 0,15 KALI & $-51,7 \%$ & $-7,6 \%$ \\
\hline $\mathbf{2 0 1 6}$ & I & 0,07 KALI & $-42,2 \%$ & $-3,2 \%$ \\
\hline & II & 0,16 KALI & $-54,3 \%$ & $-8,7 \%$ \\
\hline $\mathbf{2 0 1 7}$ & I & 0,09 KALI & $-54,4 \%$ & $-5,0 \%$ \\
\hline & II & 0,19 KALI & $-64,7 \%$ & $-12,5 \%$ \\
\hline $\mathbf{2 0 1 8}$ & I & 0,11 KALI & $-60,9 \%$ & $-6,4 \%$ \\
\hline & II & 0,22 KALI & $-64,7 \%$ & $-14,1 \%$ \\
\hline
\end{tabular}

Berdasarkan hasil penilaian kinerja diatas dapat dilihat kondisi perusahaan dari variabel Tingkat Total asset Turnover dari perusahaan ini selama tahun 2014 sampai dengan 2018 berada dibawah rata-rata industri. Hal tersebut menunjukkan bahwa kinerja keuangan PT Smartfren Telecom Tbk dalam menghasilkan penjualan dari perputaran total aset yang dimiliki dikatakan sangat rendah walaupun memiliki penjualan dan total asset yang mengalami kenaikan selama tahun 2014-2018. Tingkat Net Profit Margin dari perusahaan ini selama tahun 2014 sampai dengan 2018 sangat rendah dan berada jauh dibawah rata-rata industri. Hal tersebut menunjukkan bahwa kinerja keuangan PT Smartfren Telecom Tbk dalam memperoleh laba bersih dari penjualan dikatakan sangat rendah. Tingkat Return On Investment dari perusahaan ini selama tahun 2014 sampai dengan 2018 berada jauh dibawah rata-rata industri sektor telekomunikasi yang disebabkan oleh Tingkat perputaran Aset dan Net profit Margin yang semuanya berada dibawah rata-rata industri. Hal tersebut menunjukkan bahwa kinerja keuangan PT Smartfren Telecom Tbk dalam memperoleh pengembalian atas aset dari penjualan sangat kurang baik yang dipengaruhi oleh perputaran aset dan kemampuan perusahaan dalam menghasilkan laba bersih dari penjualannya yang kurang baik.

\section{Implikasi Penelitian}

Berdasarkan hasil penelitian tersebut dapat dikemukakan implikasi penelitian sebagai berikut:

a. Penelitian ini menemukan bahwa kinerja keuangan suatu perusahaan dapat diukur menggunakan beberapa metode. Pemilihan metode penilaian kinerja keuangan ini sangat penting untuk suatu perusahaan. Salah satu metode penilaian kinerja keuangan yang digunakan adalah metode Du Pont System. Du Pont System merupakan salah satu metode yang dapat digunakan oleh perusahaan untuk menilai kinerja keuangan dan berfokus pada profitabilitas dengan pemanfaatan aset perusahaan. Profitabilitas merupakan aspek yang sangat harus diperhatikan oleh perusahaan selain itu juga pemanfaatan aset dalam kegiatan aktivitas perusahaan sangat perlu diperhatikan.

b. Penelitian ini menemukan bahwa metode Du Pont System ini menggunakan variabel Total Asset Turnover (TATO). Dengan menggunakan variabel TATO perusahaan dapat mengetahui bagaimana kinerja keuangan perusahaan dalam mengelola asetnya sehingga dalam menghasilkan volume penjualan dari perputaran aset yang dilakukan itu sudah efisien atau belum. Dengan mengetahui hasil penilaian dari Total Asset Turnovernya maka perusahaan bisa mengambil keputusan untuk meningkatkan atau mempertahankan tingkat TATO. Perusahaan bisa meningkatkan Total Asset Turnover (TATO) dengan lebih sering untuk menjual aset yang tidak digunakan lagi dan membeli aset yang akan membantu meningkatkan hasil produksi perusahaan. Dengan meningkatnya hasil produksi perusahaan penjualan dari perusahaan pun akan ikut meningkat dan mempengaruhi perolehan laba/ keuntungan perusahaan. Dengan meningkatnya penjualan dari perputaran total aset maka akan menunjukkan perusahaan itu memiliki kinerja yang sangat baik.

c. Penelitian ini menemukan bahwa metode Du Pont System ini menggunakan variabel Net Profit Margin (NPM). Dengan menggunakan variabel NPM dalam penilaian kinerja keuangan, perusahaan bisa mengukur seberapa besar laba bersih yang didapatkan dari penjualan bersih yang diperoleh oleh perusahaan. Dengan mengetahui ukuran besarnya laba bersih dari hasil penjualan bersih yang dimiliki, perusahaan bisa mengambil keputusan. Jika rasio profit margin masih berada dibawah dari rata-rata pembanding maka perusahaan perlu untuk meningkatkan penjualan atau dengan meminimalisir beban operasional perusahaan sehingga 
laba bersih perusahaan bisa lebih meningkat. Dengan meningkatnya rasio laba bersih ini maka perusahaan dinyatakan memiliki kinerja keuangan yang sangat baik.

d. Penelitian ini menemukan bahwa metode Du Pont System ini menggunakan variabel Return On Investment (ROI). Variabel ini digunakan untuk melihat bagaimanakah kinerja keuangan suatu perusahaan jika variabel Total Asset Turnover (TATO) dan Net Profit Margin (NPM) digabungkan menjadi satu dalam satu rumus ROI $D u$ Pont System. Perusahaan bisa mengetahui bagaimana kinerja keuangan mereka sekaligus dari sisi profitabilitas dan sisi aktivitas dalam penilaian dengan menggunakan variabel ROI $D u$ Pont System. Dalam variabel ini akan diketahui seberapa efektif dan efisiennya suatu perusahaan untuk mengelola asetnya dalam memperoleh laba yang tinggi. Perusahaan bisa mengambil keputusan untuk meningkatkan atau mempertahankan laba dengan sering melakukan perputaran aset dimana menjual aset yang sudah tidak terpakai dan membeli aset yang bisa meningkatkan hasil produksi perusahaan. Selain mengelola aset, perusahaan bisa memperhatikan besarnya penjualan dan beban operasional perusahaan itu sendiri. Untuk meningkatkan laba, ada dua hal yang perlu untuk diperhatikan yaitu:

1) Meningkatkan penjualan.

2) Meminimalisir besarnya beban perusahaan.

\section{KESIMPULAN}

Berdasarkan penelitian yang dilakukan dapat ditarik beberapa kesimpulan sebagai berikut :

1. Kinerja keuangan keempat perusahaan telekomunikasi yang terdaftar di BEI pada periode tahun 2014-2018 adalah sebagai berikut:
a. Kinerja Keuangan PT
Telekomunikasi Indonesia dinyatakan sangat baik dimana tingkat Return On Investment (ROI) menurut metode $\mathrm{Du}$ Pont System menunjukkan angka diatas rata-rata industri selama tahun 2014 sampai 2018. Hal tersebut dipengaruhi oleh tingkat Net Profit Margin (NPM) dan

Total Asset Turnover (TATO) yang

berada diatas rata-rata industri.

b. Kinerja Keuangan PT XL Axiata Tbk dinyatakan baik walaupun dengan tingkat Return On Investment (ROI) menurut metode Du Pont System yang menunjukkan angka dibawah rata-rata industri selama tahun 20142018. Hal tersebut dipengaruhi oleh tingkat Net Profit Margin (NPM) yang berada diatas rata-rata industri dan Total Asset Turnover (TATO) yang berada dibawah rata-rata industri.

c. Kinerja Keuangan PT Indosat Tbk dinyatakan baik walaupun dengan tingkat Return On Investment (ROI) menurut metode Du Pont System yang menunjukkan angka dibawah rata-rata industri selama tahun 20142018. Hal tersebut dipengaruhi oleh tingkat Net Profit Margin (NPM) yang berada dibawah rata-rata industri dan Total Asset Turnover (TATO) yang berada diatas rata-rata industri.

d. Kinerja keuangan PT Smartfren Telecom Tbk dinyatakan tidak baik dimana tingkat Return On Investment (ROI) menurut metode Du Pont System menunjukkan angka dibawah rata-rata industri selama tahun 2014 sampai 2018. Hal tersebut dipengaruhi oleh tingkat Net Profit Margin (NPM) dan Total Asset Turnover (TATO) yang berada dibawah rata-rata industri.

2. Implikasi penilaian kinerja keuangan perusahaan telekomunikasi pada empat perusahaan telekomunikasi dengan menggunakan Du Pont System:

1. Penggunaan Du Pont System untuk menilai kinerja keuangan dan berfokus pada profitabilitas dengan pemanfaatan aset perusahaan. Profitabilitas merupakan aspek yang sangat harus diperhatikan oleh perusahaan selain itu juga pemanfaatan aset dalam kegiatan aktivitas perusahaan sangat perlu diperhatikan.

2. Penggunaan variabel TATO perusahaan dapat mengetahui bagaimana kinerja keuangan perusahaan dalam mengelola asetnya 
sehingga dalam menghasilkan volume penjualan dari perputaran aset yang dilakukan itu sudah efisien atau belum. Dengan mengetahui hasil penilaian dari Total Asset Turnovernya maka perusahaan bisa mengambil keputusan untuk meningkatkan atau mempertahankan tingkat TATO.

3. Penggunaan variabel NPM dalam penilaian kinerja keuangan, perusahaan bisa mengukur seberapa besar laba bersih yang didapatkan dari penjualan bersih yang diperoleh oleh perusahaan. Dengan mengetahui ukuran besarnya laba bersih dari hasil penjualan bersih yang dimiliki, perusahaan bisa mengambil keputusan.

4. Perusahaan bisa mengetahui bagaimana kinerja keuangan mereka sekaligus dari sisi profitabilitas dan sisi aktivitas dalam penilaian dengan menggunakan variabel ROI Du Pont System. Dalam variabel ini akan diketahui seberapa efektif dan efisiennya suatu perusahaan untuk mengelola asetnya dalam memperoleh laba yang tinggi.

\section{SARAN}

Berdasarkan hasil penelitian mengenai penilaian kinerja keuangan perusahaan pada empat perusahaan telekomunikasi yang terdaftar di BEI pada tahun 2014-2018 dengan menggunakan Metode Du Pont System, maka penulis memberikan masukan atau saran sebagai berikut:

1. PT Telekomunikasi Indonesia Tbk diharapkan dapat mempertahankan kemampuannya dalam mengelola aset untuk meningkatkan penjualannya dan mempertahankan tingkat laba perusahaan yang sudah maksimal dibandingkan dengan perusahaan sejenisnya.

2. PT XL Axiata Tbk dan PT Indosat Tbk diharapkan mampu meningkatkan kemampuannya dalam mengelola aset sehingga dalam menghasilkan penjualannya bisa lebih maksimal dan lebih memperhatikan tarif produk dan beban - beban perusahaan agar terhindar dari kerugian.

3. PT Smartfren Telecom Tbk diharapkan mampu meminimalisir angka kerugian yang dialami selama tahun 2014 - 2018.

Hal tersebut dapat dilakukan dengan meningkatkan kemampuan dalam mengelola aset secara efisien dan efektif sehingga mampu menaikkan angka penjualan perusahaan yang akan membantu menurunkan tingkat kerugian perusahaan.

4. Kinerja keuangan tidak hanya dipengaruhi oleh kondisi internal perusahaan tapi juga kondisi eksternal perusahaan. Perusahaan harus lebih waspada dengan keadaankeadaan sosial, ekonomi dan politik karena akan sangat berdampak langsung pada kinerja keuangan perusahaan.

5. Diharapkan untuk peneliti selanjutnya agar lebih memperluas jangkauan penelitian mengenai kinerja keuangan perusahaan dengan menambah sampel atau menggunakan metode analisis lainnya.

\section{DAFTAR PUSTAKA}

Arikunto, S. (2013). Prosedur Penelitian Suatu Pendekatan Praktik. Jakarta:Rineka Cipta.

Cooper, Donald R., Schindler, P. S. (2017). Metodologi Penelitian Bisnis (Edisi12). Jakarta: McGrawHill/Irwin dan Salemba Empat.

Prastowo, Dwi \& Juliaty, Rifka. (2010). Analisis Laporan Keuangan Konsep dan Aplikasi. Yogyakarta : Unit Penerbit \& Percetakan AMP YKPN.

Dwiningsih, Sri. (2018). Analisis Du Pont System untuk Menilai Kinerja Keuangan Perusahaan (Studi pada perusahaan Property \& real Estate LQ45 Yang terdaftar di Bursa Efek Indonesia Periode Tahun 2013-2015). Jurnal Inovasi Bisnis dan Manajemen Indonesia, Volume 1, No.2, Maret 2018:105 117.

Fahmi, Irham (2015). Analisis Laporan Keuangan. Bandung:Penerbit Alfabeta.

Hanafi, Mamduh.,\& Halim, Abdul (2016). Analisis Laporan Keuangan. Edisi Kelima, Cetakan Pertama.Yogyakarta:UPP STIM YKPN.

Horne, J.C.V \& Wachhowichz, J.M. (2011). Prinsip-prinsip Manajemen Keuangan. Jakarta: Salemba Empat. 
Irmaningsih, Dede (2017). Analisis Penerapan

Du Pont System untuk mengukur Kinerja Keuangan Perusahaan (studi pada sub sektor Perusahaan Makanan dan Minuman yang terdaftar di BEI periode 2012-2015). 18 Februari, 2019. Universitas Lampung: Fakultas Ilmu Sosial dan Ilmu Politik.

Kasmir (2015). Analisis Laporan Keuangan, Edisi kelima, cetakan pertama. Jakarta: PT. Raja Grafindo Persada.

Lianto, David. (2013), Penilaian Kinerja Keuangan Perusahaan Menggunakan Analisis DuPont System. Jurnal Nasional: Jurnal JIBEKA, Volume 7, No.2, Agustus 2013:25-31.

Lyn, Fraser \& Aileen, Ormiston. (2015). Memahami Laporan Keuangan Edisi Kesebelas. Jakarta: PT.Indeks.

Riyanto, Bambang. (2010). Dasar-Dasar Pembelanjaan Perusahaan, Edisi keempat, Cetakan kesepuluh. Yogyakarta: BPFE Yogyakarta.

Uma, S., \& Roger, B. (2017). Metode Penelitian Untuk Bisnis (Edisi 6). Jakarta: Wiley dan Salemba Empat.

Sugiyono, (2011). Metode penelitian kuantitatif kualitatif dan R\&D. Bandung : Alfabeta.

Wuryaningsih dan Moh Dziqron. (2014). Penerapan Du Pont System Untuk Mengukur Kinerja Keuangan Perusahaan (Studi Pada Perusahaan Semen Yang Terdaftar di BEI Tahun 2007-2011). Jurnal Ilmiah. Volume 6. No.1. Surakarta: Universitas Muhammadiyah Surakarta.

Kominfo optimistis industri

telekomunikasi cerah di 2019,

https://www.indotelko.com/read/1546223598/k ominfo-industri-2019 